\title{
Comparison of a rapid, quantitative and automated assay for urinary luteinizing hormone (LH), with an LH detection test, for the prediction of ovulation
}

\author{
P.Bischof ${ }^{1}$, P.G.Bianchi and A.Campana \\ Clinic of Infertility and Gynaecological Endocrinology, Department \\ of Obstetrics and Gynaecology, University of Geneva, 1211 \\ Geneva, Switzerland \\ ${ }^{1}$ To whom correspondence should be addressed
}

The prediction of ovulation is necessary for oocyte aspiration in a spontaneous cycle and can be reliably achieved only by measuring luteinizing hormone (LH). Since radioimmunoassays of LH take too long for repeated measurements on the same day, we evaluated the possibility of adapting a rapid and fully automated assay of serum $\mathrm{LH}$ for use with urine samples. The study group comprised spontaneously ovulating women ( 38 cycles) who requested artificial insemination. Their serum oestradiol $\left(E_{2}\right)$ levels, ultrasound profile (US) and thrice daily urinary LH levels were determined from day 10 of their menstrual cycle. These patients were followed until US signs of follicular rupture were recorded. In all patients, a well-defined LH peak was measured in the urine. This peak lasted $12-15 \mathrm{~h}$ and was followed in 35 cycles (no US available for 3) by follicular rupture $9-51 \mathrm{~h}$ later. The data were grouped according to the time of the LH peak on day 0 . Patients experiencing an $\mathrm{LH}$ peak between $0300 \mathrm{~h}$ and $0700 \mathrm{~h}$ on day 0 had significantly lower levels of $E_{2}$ on day 0 compared to those with an LH peak between $2200 \mathrm{~h}$ and midnight. This is due to the fact that in the patients with an LH peak between $0300 h$ and $0700 h, E_{2}$ levels were already decreasing (from day 1 to day 0 ), whereas in those with the LH peak between $2200 \mathrm{~h}$ and midnight $E_{2}$ levels were still increasing on the morning of day 0 . We conclude that the 30-min IMX LH assay is a reliable, rapid and readily acceptable method for measuring urinary $\mathrm{LH}$ and for the prediction of ovulation.

Key words: luteinizing hormone/IMX-assay/ovulation prediction/ultrasonography

\section{Introduction}

The prediction and detection of ovulation are often critical in the treatment of infertility. Many different parameters have been used to predict ovulation including basal body temperature (Moghissi, 1976; Lenton et al., 1977), cervical mucus and circulating levels of luteinizing hormone $(\mathrm{LH})$, oestradiol $\left(\mathrm{E}_{2}\right)$ and progesterone (P) (Kerin et al., 1981; Collins, 1985; Bryce et al. 1982). Measurements of vaginal impedance (Albrecht $e t$ al., 1985) or recording of Mittelschmerz (lower abdominal pain at mid-cycle)
(O'Herlihy et al., 1980) have been described as preovulatory signs with a rather poor degree of ovulation prediction.

Follicular size and recent ovulation can be detected by ultrasonography with great accuracy (Renaud et al., 1980; Bryce et al., 1982). This method is not infallible in detecting ovulation since it shows follicular rupture and not egg release (ElkindHirsch $e t$ al., 1986). Determining follicular size by ultrasound in order to predict ovulation is highly inaccurate since the period until ovulation varies greatly among women with equal follicular size (Renaud et al., 1980; Kerin et al., 1981; Bryce et al., 1982).

Quantitative (Kerin et al., 1980) or semiquantitative (Lloyd and Coulam, 1989) measurements of urinary LH have been found superior to most other methods used to predict ovulation. Since conventional methods of radioimmunoassay of LH are too long for repeated measurements during the same day, we evaluate here the possibility of adapting a rapid ( $30 \mathrm{~min})$, quantitative and fully automated assay of serum LH for use in urine samples.

Materials and methods

\section{Patients}

A total of 32 spontaneously ovulating women between 28 and 37 years of age were included in this study. All patients attended our infertility clinic for artificial insemination. None received any medication or hormonal therapy during the evaluated cycles $(n=38)$. Blood samples were taken daily between $0800 \mathrm{~h}$ and $0900 \mathrm{~h}$ onto ethylenediaminetetraacetic acid (EDTA, $2 \mathrm{mg} / \mathrm{ml}$ ) starting on day 10 of the cycle until ovulation (see below). During this period, the patients were asked to collect three urine samples per day (morning, afternoon and evening) and to record the time of sampling.

\section{Ultrasonographic monitoring}

Ultrasonographic imaging of the ovaries was performed with a Toshiba Sonolayer-L fitted with a $5 \mathrm{MHz}$ vaginal transducer (Medical System, Aubonne, Switzerland). Transvaginal ultrasonographic scans were begun on day 10 of the menstrual cycle and continued daily until follicular rupture was documented. Ovulation was defined as a reduction in follicular size of at least $5 \mathrm{~mm}$ (Check et al., 1990). Ultrasonographic monitoring was always performed between $0800 \mathrm{~h}$ and $0900 \mathrm{~h}$. Follicular size was recorded by measuring two right-angle diameters for each follicle and then taking the mean of both diameters.

\section{Hormone assays}

$\mathrm{E}_{2}$ was measured daily in the plasma samples using a commercially available radioimmunoassay (Biomérieux, Marcy L'Etoile, France). LH was measured daily in urine samples by an 
automated microparticle enzyme immunoassay for serum $\mathrm{LH}$ (IMX, Abott, Cham, Switzerland) using a mouse anti-human LH monoclonal antibody. The sensitivity of this assay for serum LH was determined by the manufacturer at $0.5 \mathrm{mIU} / \mathrm{ml}$ and the coefficient of variation at $3.6 \%$. The day of the urinary LH peak (highest value) was designated day 0 .

In order to compare the IMX assay with a standard "Ovulation test", 103 consecutive urine samples were obtained from 43 patients. LH was measured with the IMX and with a semiquantitative LH detection assay (sensitivity $50 \mathrm{IU} / \mathrm{l}, \mathrm{LH}$ colour, Organon, Oss, The Netherlands). All the LH detection assays were judged by the same technician. Results were evaluated statistically by Student's $t$-test for paired or unpaired variables, when appropriate, using the Fastat program (Systat, Evanston, IL, USA) on a Macintosh IICX computer.

\section{Results}

\section{Validation of the urinary $\mathrm{LH}$ assay}

In order to evaluate the accuracy of our assay and a possible matrix effect, a serum-based sample routinely used as an internal control and containing a known concentration of $\mathrm{LH}$ was serially diluted with urine from a male volunteer and measured on the IMX (Table I). When the serum-based sample was diluted 1:2

Table I. Effect of unne on the measurements of LH by the IMX assay

\begin{tabular}{lll}
\hline & Dilution & LH mIU/ml \\
\hline Serum-based control & Undiluted & 124.90 \\
& $1: 2$ & 114.7 \\
& $1: 4$ & 121.8 \\
& $1: 8$ & 122.7 \\
& 116 & 127.0 \\
Male urine & $1: 32$ & 122.9 \\
& Undiluted & 1.96 \\
\hline
\end{tabular}

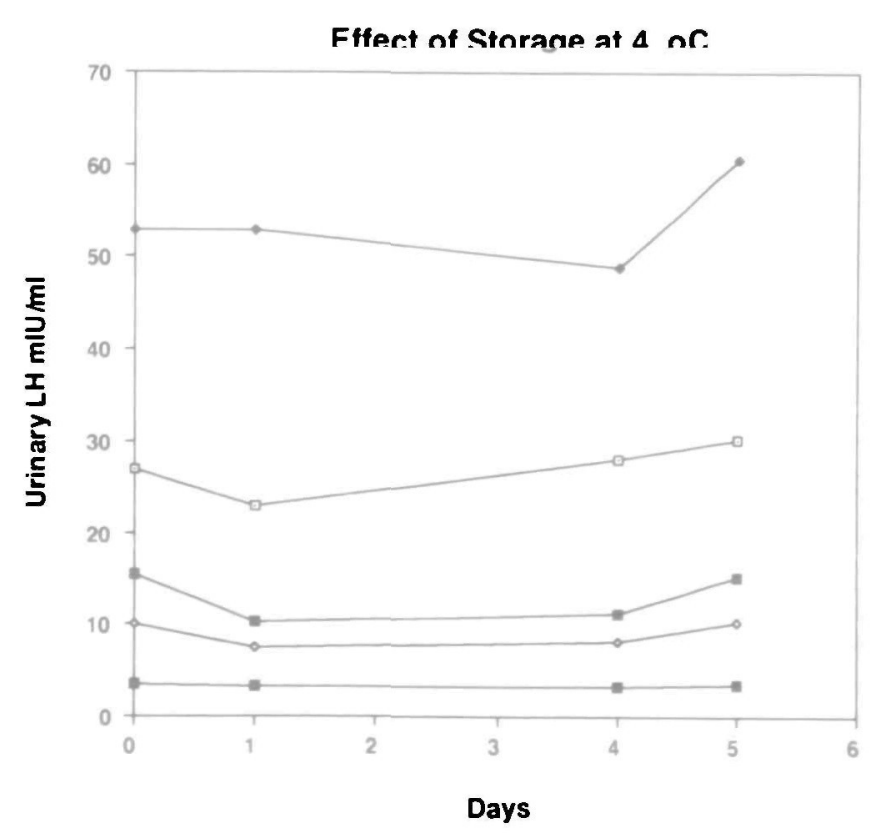

Fig. 1. Effect of storage at $4^{\circ} \mathrm{C}$ on the measurements of urinary LH by IMX assay. with urine, the measured level of LH was lower than that found in the undiluted control. Higher dilutions of the control sample gave $\mathrm{LH}$ values which were indistinguishable from the undiluted serum control (Table I).

The effect of storage on the IMX LH determination was also investigated. As shown in Figure 1, urine samples could be stored up to five days at $4^{\circ} \mathrm{C}$ without significant loss of immunoreactive LH. In contrast, freezing and thawing dramatically reduced the measurable concentration of LH (results not shown).

Table II compares the results obtained with the quantitative IMX urinary LH assay with those of the LH colour assay. The correlation between the two assays was high $(n=103$, $r=0.688, P<0.001)$ but an important overlap was observed

Table II. Comparison ${ }^{\mathrm{a}}$ between IMX and LH colour assays $(n=103)$

\begin{tabular}{llrrr}
\hline LH colour & \multicolumn{4}{l}{ IMX LH, IU/1 } \\
\cline { 2 - 5 } & $n$ & Mean & \multicolumn{1}{c}{ SD } & \multicolumn{1}{c}{ Range } \\
\hline Negattve & 62 & 88 & 6.0 & $(0.5-28.6)$ \\
Borderline $^{\mathrm{b}}$ & 19 & 20.8 & 6.1 & $(10.3-36.8)$ \\
Positive $^{n}$ & 22 & 51.1 & 20.4 & $(17.2-95.2)$ \\
\hline
\end{tabular}

${ }^{\mathrm{a}} r=0.688, P<0.001$.

${ }^{\mathrm{b}}$ Borderline: colour between a positive and a negative test.

TIME OF URINARY LH PEAK ON DAY O
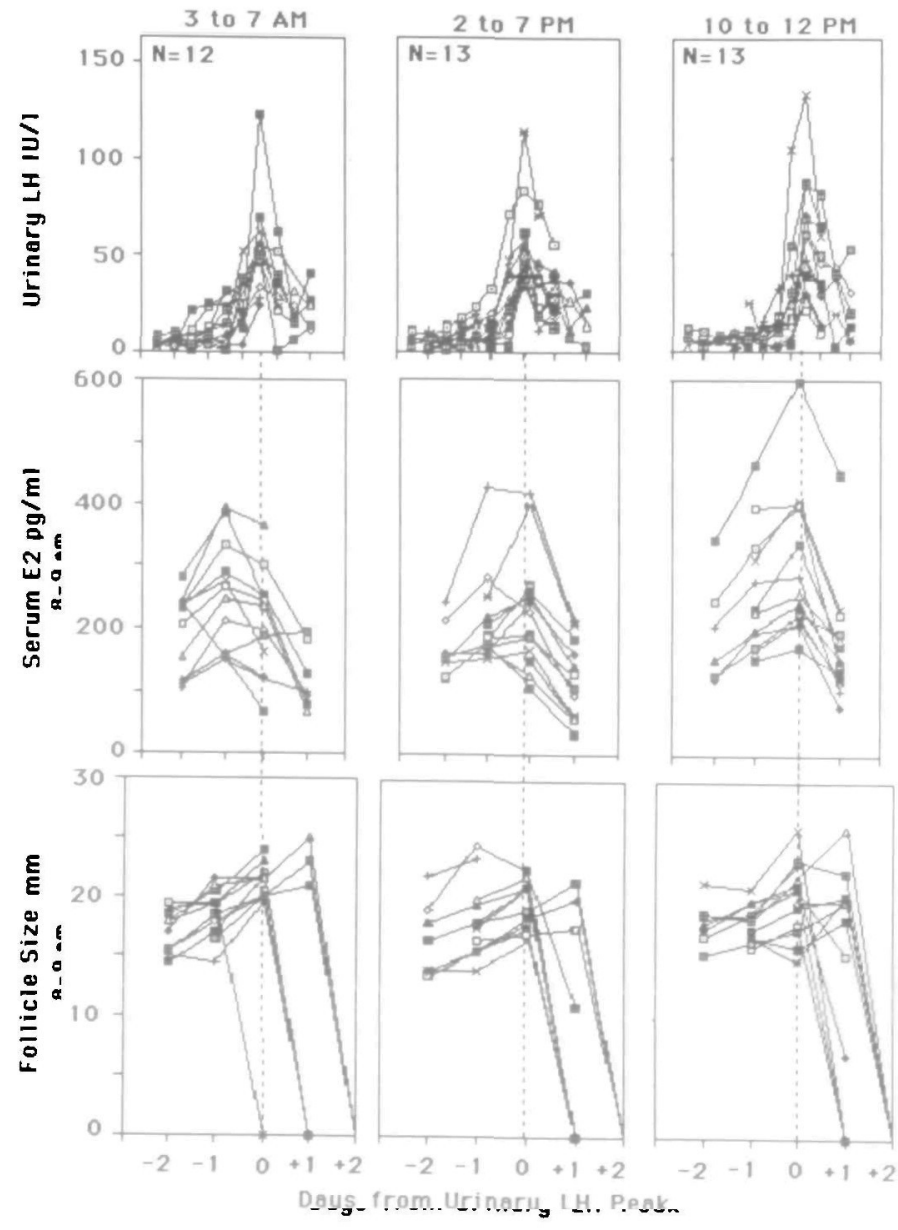

Fig. 2. Urinary LH levels, serum $E_{2}$ and follicular size measured once a day at $0800 \mathrm{~h}$ to $0900 \mathrm{~h}$ from day 2 to ovulation. represented according to the time of the LH peak on day 0 . 
Table III. Urine and blood parameters of the 38 spontaneous cycles according to the time of the LH peak

\begin{tabular}{|c|c|c|c|c|c|c|c|c|c|}
\hline & \multicolumn{9}{|c|}{ Urinary LH peak between: } \\
\hline & \multicolumn{3}{|c|}{$0300 \mathrm{~h}$ to $0700 \mathrm{~h}$} & \multicolumn{3}{|c|}{$1400 \mathrm{~h}$ to $1900 \mathrm{~h}$} & \multicolumn{3}{|c|}{$2200 \mathrm{~h}$ to midnight } \\
\hline & $n$ & Mean & SD & $n$ & Mean & SD & $n$ & Mean & SD \\
\hline Serum $E_{2}$ on day $1(\mathrm{pg} / \mathrm{ml})$ & 12 & 251.8 & 88.6 & 12 & 210.9 & 78.2 & 12 & 259.3 & 98.2 \\
\hline Serum $\mathrm{E}_{2}$ on day $0(\mathrm{pg} / \mathrm{ml})$ & 12 & $207.8^{\mathrm{a}}$ & 83.1 & 13 & $225.8^{\mathrm{b}}$ & 95.9 & 13 & $304.6^{\mathrm{c}}$ & 119.6 \\
\hline Difference in $E_{2}$ between day 1 and day $0(\mathrm{pg} / \mathrm{ml})$ & 12 & $-23.2^{\mathrm{d}}$ & 25.3 & 12 & $20^{e}$ & 32.6 & 12 & $16.1^{f}$ & 9.4 \\
\hline
\end{tabular}

Unpaired Student's $t$-test. a vs b, NS; a vs c, $P<003$; d vs e, $P<0.05$; d vs f, $P<0.001$.

Paired Student's $t$-test: d, $P<0.01$ : e. NS; f. $P<0.001$.

${ }^{\prime} E_{2}$ and follicle sizes as measured once a day between $0800 \mathrm{~h}$ and $0900 \mathrm{~h}$.

between negative and positive LH colour tests. The highest value observed for a negative test was $28.6 \mathrm{IU} / \mathrm{l}$ and the lowest value for a positive test was $17.2 \mathrm{IU} / \mathrm{l}$. About $20 \%$ of the colour tests developed a colour which was between a positive and a negative result and the LH values ranged from 10.3 to $36.8 \mathrm{IU} / 1$ in these borderline samples (Table II).

\section{Urinary $\mathrm{LH}$ and follicular rupture}

All the 38 cycles studied had a well-defined LH peak in the urine (highest value at least twice the basal level for each patient in two successive samples). These cycles were divided into three groups according to the time at which the highest urinary $\mathrm{LH}$ value had been recorded on day $0: 0300 \mathrm{~h}-0700 \mathrm{~h}, n=12$; $1400 \mathrm{~h}-1900 \mathrm{~h}, n=13 ; 2200 \mathrm{~h}-$ midnight, $n=13$ (Figure 2). The mean concentration of LH peaks did not differ between the groups (Table III), the levels ranging from 21.0 to $133.0 \mathrm{IU} / \mathrm{l}$. Post-LH peak ultrasound scans could not be performed in 3 patients but in all the remaining 35 , follicular rupture was documented at ultrasonography. In the group of patients with a urinary $\mathrm{LH}$ peak between $0300 \mathrm{~h}$ and $0700 \mathrm{~h}$ on day 0 , follicular rupture was seen in one patient on the same day (Figure 2), i.e. about $4 \mathrm{~h}$ after the highest $\mathrm{LH}$ concentration in the urine (63 IU/l) had been detected. This patient had, however, an elevated LH concentration $(52 \mathrm{IU} / \mathrm{l})$ in the urine sample collected in the evening $(2230 \mathrm{~h})$ of day -1 . In all the other patients, follicular rupture was seen on day 1 or 2 after the LH peak. The time between the urinary LH peak and follicular rupture (as documented by daily ultrasound scans) varied between $9-51 \mathrm{~h}$ with no significant differences between the groups (Figure 3 ).

\section{Serum $E_{2}$ and follicular rupture}

Mean serum $E_{2}$ concentrations were similar for all three groups on day 1 . Day $0 \mathrm{E}_{2}$ levels in the group of patients with a urinary LH peak between $0300 \mathrm{~h}$ and $0700 \mathrm{~h}$ were significantly lower than those in the group with a peak between $2200 \mathrm{~h}$ and midnight $(P<0.03$, Table $\mathrm{WI})$. The difference in $\mathrm{E}_{2}$ between day -1 and day 0 was statistically significant between the groups $(P<0.05$ to $P<0.00$ !, Table III): the patients with the LH peak between $0300 \mathrm{~h}$ and $0700 \mathrm{~h}$ showed a significant reduction in $\mathrm{E}_{2}$ from day -1 to day $0(-23.2 \mathrm{pg} / \mathrm{ml}, P<0.01$, Table III) whereas the patients with an LH peak between $1400 \mathrm{~h}$ and $1900 \mathrm{~h}$ had unchanged $E_{2}$ levels and those with the LH peak between $2200 \mathrm{~h}$ and midnight showed a significant increase in $\mathrm{E}_{2}$ concentrations $(+16.1 \mathrm{pg} / \mathrm{ml}, P<0.001$, Table III). This was
TIME FROM URINARY LH PEAK TO FOLLICULAR RUPTURE

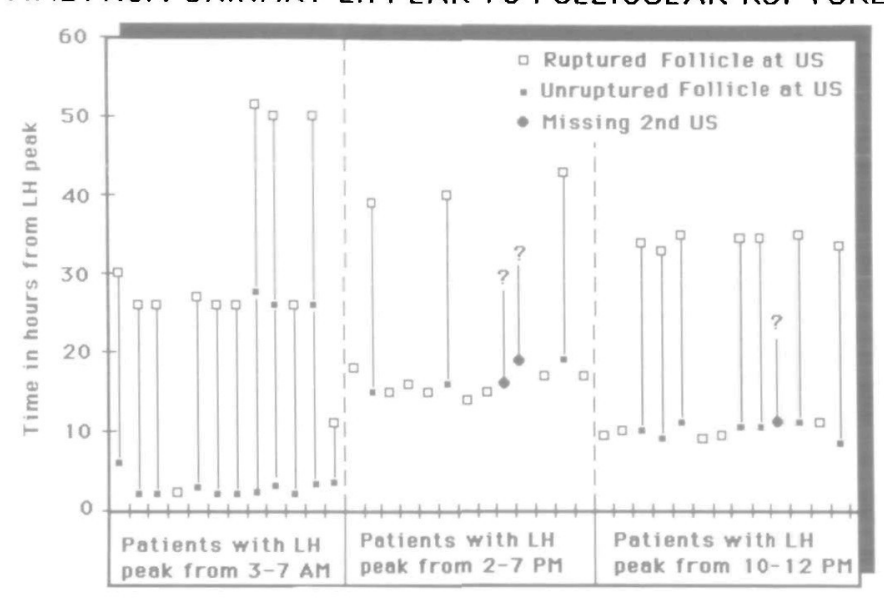

Fig. 3. Time between urinary LH peak and ultrasonic evidence of follicular rupture.

because the patients with an $\mathrm{LH}$ peak between $0300 \mathrm{~h}$ and $0700 \mathrm{~h}$ experienced their highest $E_{2}$ level on day 1 (11 out of 12 patients) whereas all patients with an LH peak between $1220 \mathrm{~h}$ and midnight had their serum $\mathrm{E}_{2}$ peak in the morning of day 0 . It is interesting to note that the follicular size on day 0 was similar in all patients (Table III).

\section{Discussion}

In clinical practice, semiquantitative assays of urinary LH are widely used to predict ovulation. Usually the patients are instructed to use a dipstick method daily to test their morning urine (O'Herlihy et al., 1980; Lloyd and Coulam, 1989; Grinsted et al., 1989; Paz et al., 1990). This approach to ovulation prediction has been found superior to many other methods including assays of serum LH or $\mathrm{E}_{2}$ (Grinsted et al., 1989). In our hands, rapid and quantitative urinary LH measurements proved to be superior to the dipstick method. By sampling urine thrice daily and evaluating LH quantitatively, the precise timing of the preovulatory LH surge and peak is obtained. As shown in Table III, a strict time-dependent correlation between serum $E_{2}$, evidence of follicular rupture and urinary LH peak is observed.

According to the present data, an increased level of urinary LH can be observed over a period of 12 to $15 \mathrm{~h}$ so that one might 
expect a dipstick method with a sensitivity of 50 IU/1 used once per $24 \mathrm{~h}$ to miss a certain number of $\mathrm{LH}$ peaks. The precise timing of $\mathrm{LH}$ secretion is of paramount importance for oocyte aspiration in spontaneous cycles. It is, however, debatable as to whether such a precise timing of the $\mathrm{LH}$ peak is necessary for artificial insemination. This is particularly true if one takes into account the lack of knowledge about the survival rate of spermatozoa in the female genital tract. The rapidity, the ease and the noninvasiveness of the LH measurement described here would argue in favour of its widespread use.

Compared to the LH colour technique, the quantitative method probably underestimates the real concentration of $\mathrm{LH}$ in the urine since LH colour-positive samples (sensitivity $50 \mathrm{IU} / \mathrm{l}$ ) have registered only $17 \mathrm{IU} / \mathrm{l}$ of $\mathrm{LH}$ with the quantitative assay. This might be because the IMX uses a monoclonal antibody, raised against serum LH (since this method was designed for serum LH), which probably only partially recognizes urinary LH. In the present study, follicular rupture was documented by ultrasound scans. However, since these have only been performed on a daily basis, our estimation of the time elapsed between the LH peak and ovulation is probably over-estimated by several hours. Previous investigations described the onset of the urinary LH surge to occur beween 12 and $44 \mathrm{~h}$ before follicular rupture (O'Herlihy et al., 1980; Singh et al., 1984; Vermesh et al., 1987). This is in keeping with the interval observed in the present study $(9-51 \mathrm{~h})$ between the LH peak an follicular rupture.

In conclusion, the IMX assay of urinary $\mathrm{LH}$ proved to be a reliable method of ovulation prediction which is readily accepted by the patients and avoids the need for frequent venepuncture. Furthermore, the assay offers the advantage of being fully automated and very rapid, allowing 24 samples to be processed within 30 min.

\section{Acknowledgements}

The authors wish to thank C.Gruffat for technical help and M.Gharbi for typing the manuscript.

\section{References}

Albrecht;B.H., Fernando,R.S., Regas,J. and Betz,G. (1985) A new method for prediction and confirming ovulation. Fertil. Steril., 44, 200-207.

Bryce,R.L., Shuter,B., Sinosich,M.J., Stiel,J.N., Picker,R.H. and Saunders,D.M. (1982) The value of ultrasound, gonadotropin and estradiol measurements for precise ovulation prediction. Fertil. Steril., 37, 42-47.

Check,J.H., Adelson,H.G., Dietterich,C. and Stern,J. (1990) Pelvic sonography can predict ovum release in gonadotrophin-treated patients as determined by pregnancy rate. Hum. Reprod., 5, 234-236.

Collins,P.W. (1985) Hormonal indices of ovulation and the fertile period. Adv. Contracept., 1, 279-283.

Elkind-Hirsch,K., Goldzieher,J.W., Gibbons,W.E. and Besch,P.K. (1986) Evaluation of the Ovustick urinary luteinizing hormone kit in normal and stimulated menstrual cycles. Obstet. Gynecol., 67 . $450-456$.

Grinsted,J., Jacobsen,J.D., Grinsted,L., Shantz,A., Stenfoss,H.H. and Nielsen,S.P. (1989) Prediction of ovulation. Fertil. Steril., 52, $388-393$.

Kerin,J.F., Wames,G.M., Crocken,J., Broom,T.G., Ralph,M.M., Mattews,C.D., Seamark,R.F. and Cox.L.W. (1980) 3-Hour urinary radioimmunoassay for luteinizing hormone to detect onset of preovulatory LH surge. Lancet, ii, 430-431.

Kerin,J.F., Edmonds,D.K., Warnes,G.M., Cox,L.W., Seamark,R.F., Mattews,C.D., Young,G.B. and Baird,D.T. (1981) Morphological and functional relationships of graafian follicle growth to ovulation in women using ultrasonic laparoscopic and biochemical measurements. Br. J. Obstet. Gynaecol., 88, 81-88.

Lenton,E.A., Weston,G.A. and Cook,I.D. (1977) Problems in using basal body temperature in an infertility clinic. Br. Med. J., 1, 803-805.

Lloyd,R. and Coulam,C.B. (1989) The accuracy of urinary luteinizing hormone testing in predicting ovulation. Am. J. Obstet. Gynecol., 160, 1370-1375.

Moghissi,K.S. (1976) Accuracy of basal temperature for ovulation detection. Fertil. Steril., 27, 1415-1417.

O'Herlihy,C., Robinson,H.P. and De Crespigny,L.C. (1980) Mittelschmerz is a preovulatory symptom. Br. Med. J., 280, 986-989.

Paz,G., Yogev,L., Gottreich,A., Rotem,R., Yavetz,H. and Homonnai,Z.T. (1990) Determination of urinary luteinizing hormone for prediction of ovulation. Gynecol. Obstet. Invest., 29, 207-210.

Renaud,R.L., Macles,J., Dervain,I., Ehert,M.C., Aron,C., Plas-Roser,S., Spira,A. and Pollack,H. (1980) Echographic study of follicular maturation and ovulation during the normal menstrual cycle. Fertil. Steril., 33, 272-278.

Singh,M., Saxema,B.B. and Rathnam,P. (1984) Clinical validation of enzyme immunoassay of human luteinizing hormone $(\mathrm{hLH})$ in the detection of the preovulatory luteinizing hormone $(\mathrm{LH})$ surge in urine. Fertil. Steril., 41, 210-213.

Vermesh,M., Kletzky,O.A., Davajan,V. and Israel,R. (1987) Monitoring techniques to predict and detect ovulation. Fertil. Steril., 47, 259-264.

Received on August 31, 1990; accepted on November 26, 1990 